\title{
The Promotion and Protection Human Rights under Vietnam's Civil Law
}

\author{
Duong Quynh $\mathrm{Hoa}^{1}$ \\ ${ }^{1}$ Institute of State and Law, Vietnam Academy of Social Science, Hanoi, Vietnam \\ Correspondence: Duong Quynh Hoa, Institute of State and Law, Ngo Thi Nham, Hai Ba Trung District, Hanoi, \\ Vietnam. Tel: 84-43-978-4637. E-mail: dqhoa77@gmail.com
}

Received: February 26, 2017

Accepted: April 6, 2017 Online Published: June 1, 2017

doi:10.5539/jpl.v10n3p182

URL: https://doi.org/10.5539/jpl.v10n3p182

\begin{abstract}
This article analyzes and assesses Vietnam's civil law for the promotion and protection human rights, the successes and limitations of their implementation in practice. The research findings show that over the past years, the Civil Code has laid a firm ground for remarkable successes in the promotion and protection human rights, especially, not only of Vietnamese but also foreigners living and working in Vietnam. The code is deemed compliant with international human rights conventions, laws and practices. In the Civil Code, however, there remain some certain limitations. For example a number of provisions of the current Civil Code fail to meet the human rights legislation or do not really create favourable conditions for the promotion and protection human rights in the economic and social domains. Our objective aims to outline the theoretical bases and analyze, assess regulations on human rights provided for in the Civil Code of Vietnam at present, thence proposing some solutions for improving legal regulations and contributing to ensure human rights in the legal system of Vietnam in general and in the Civil Code in particular.
\end{abstract}

Keywords: human rights, civil law, promotion and protection human rights, Vietnam

\section{Introduction}

The movement of the socialist-oriented market economy, along with changes in the international integration process, has enormous impact on the activity of promotion and protection human rights under Vietnam's civil law. On the one hand, the positive improvements of the socio-economic conditions make it possible for activities of promotion and protection human rights and solving human rights problems; thus helping change the legal thinking on human rights. Nevertheless, this process also gives rise to several negative impacts on the implementation of human rights, such as increasing newly relevant issues (land and real estate ownership; protection of consumers' rights; environmental rights, etc.), or increasing the impact of the law and international human rights mechanism, etc. On the other hand, in parallel with the socio-economic development, there is also a tendency of human rights violations in both quantity and impact degree in Vietnam. Repetitive serious problems have been occurring recently, including the case of pollutant emissions from Formosa facilities, the matters of posting misinformation on social networking sites, the issue of freedom of religion within the framework, and so on. This situation requires that there should be a legal system in general and a civil law system in particular with the statutory regulations that can ensure human rights, and provide the people and management bodies with sufficient legal grounds for carrying out their activities.

In this context, we have selected the research subject that focuses on "the promotion and protection human rights under Vietnam's civil law". On that basis, we propose some solutions for improving the quality and performance of activities of promulgating legal documents and ensuring the implementation of regulations on the promotion and protection human rights, thus helping improve human rights in the legal system of Vietnam in general and in civil law in particular.

\section{The Theoretical Framework of Human Rights and the Promotion and Protection Human Rights}

\subsection{Nature, Definitions and Theories of Human Rights}

At present, there are numerous definitions of human rights with different ways of approaching and presenting the origin and nature of human rights. As early as in the 17th, 18th centuries, researchers such as Crotius, Hobbes, Kant, Locke, Spinoza, Rousseau did their researches and provided their concepts of human rights. Accordingly, 
human rights are the natural rights that lay in the natural law and higher than state law. Jacques Mourgon (1995) also provided a concept of human rights in his research, according to which, "Human rights" are the available privileges of each individual. Every individual, irrespective of sex, race, religion, social position...have human rights since he or she was born. In a report of the United Nations, human rights are defined as the global legal protection that has the effect of protecting individuals from damage to their human dignity, authorities and basic freedom (United Nations, 2006).

In Vietnam, there are also different definitions of human rights as proposed by researchers. However, the concept of human rights was first brought in the 1992 Constitution 1, and in the 2013 Constitution for the first time in history of constitutionalism, "human rights" became the title of the Chapter, instead of being simply referred to as "citizens" basic rights and obligations" as provided for in the 1992 Constitution and the previous ones. Accordingly, human rights are defined as the standards acknowledged and observed by the community, as the result of a long historical process of evolution and development of society. All the rights are attached to one another in dialectical correlations, i.e. individual rights always go together with social obligations. In addition, according to several legal experts and research agencies over the world, human rights are also construed as the natural, coherent and objective needs of humans, and are acknowledged and protected in national law and international legal agreements.

The nature of human rights can be expressed through the five basic contents as follows: (i) human rights are a special, imprescriptible kind of right in moral terms, without discriminating races, nationalities or members of any specific social groups; (ii) human rights are the social values, belonging to each individual person; (iii) human rights attach to the nature of each state. There are different manifestations in the relationship between the State and individuals, depending on the form of the State mechanism, and the balance of power and classes in society; (iv) human rights reflect the development and have social characteristics; (v) human rights are formed and developed under the influence of ideology, culture, tradition, nation, religion, political regime, regulations on human rights of a country imbued with the national traditions and culture of that country (Jack, 2007).

Nowadays, in the world there are two main schools with two opposing points of view on the origin and human rights, namely the theory of natural rights and the theory of jurisdictional rights. According to the theory of natural rights, human rights are the inborn and inherent rights that have been established since every individual is born. Neither individuals nor states may give or deprive individuals of their human rights (Eran Shor et al., 2016). Contrary to the theory of natural rights, the theory of jurisdictional rights purports that human rights are not the rights available, but instead all the rights, including human rights, must be acknowledged and decodified by the State into legal norms in the national legal system. According to this theory, human rights are the rights stipulated by law (Dan and Jonathan, 2008). Both the theories generally impact on large-scale philosophical, political, social, moral, legal issues. Today, the definition of the reasonableness and unreasonableness of these theories still remains one of the controversial matters in both theory and practice (Eran Shor et al. 2016).

\subsection{Theory of Promotion and Protection Human Rights in the Domain of Civil Law}

\section{* Human rights in the domain of Civil Law}

Civil law primarily includes all the norms of civil law that have been promulgated and ensured to be enforced by competent State bodies in order to regulate asset relationships and non-asset personal relationships or relationships to assets of individuals, juridical persons and other subjects, based on legal equality, self-determination, rights to take civil legal proceedings and asset liability of the people involved in such relationships (Edita et al. 2016).

The regulated objects of the Civil Code are groups of asset relationships and personal relationships. Asset relationships are interpersonal relationships through assets in the form of means of production or means of consumption or services for transferring, repairing such assets in the processes of manufacturing, distributing, consuming. Assets in the domain of Civil Law include real things, money, valuable papers and property rights such as houses, shares, currencies, etc. Personal relationships are interpersonal relationships concerning immaterial benefits, non-economic value, currency inconvertibility and non-transferability and in a close association with certain individuals, organizations (Jack Donnelly, 2007). This relationship represents the appreciation of society for individuals or organizations.

In combination with the human rights mentioned above, the concept of human rights in the domain of Civil Law is construed as the natural, inherent and objective needs, benefits of humans as recognized and protected in the civil law system of a country, codified and guaranteed to be enforced by a system of management bodies in the domain of Civil Law. Human rights in the domain of civil law of a country are under the influence of ideology, culture, tradition, nation, religion, political regime, regulations on human rights of a country imbued with the 
national traditions and culture of that country.

Human rights in the domain of Civil Law consist of three basic groups, including: (i) political rights; (ii) social, economic and cultural rights, and (iii) personality rights (Mike, 2016).

(i) Civil and political rights are the rights assured by the State, so that any person whose personality, economic, cultural, social rights are violated will all receive effective consequence remedies. At the same time, their request for remedies will be assured to be addressed by competent bodies. Civil and political rights are one of the important means to help the people protect their own legal rights and benefits. Some basic human rights in the group of civil and political rights under Articles 6 to 27 of the International Convention on Civil and Political Rights 1966 include: the right to physical entity, i.e. the right to live, without being tortured and enslaved; the right to personal freedoms and safety, i.e. the right not to be arrested and imprisoned for non-plausible reasons; the right to equality before the law, and any indictments must comply with legal order. The accused of criminal offences have the right to be presumed innocent until proven guilty. The Right to personal freedoms is construed as freedom of transfer, freedom of thought, freedom of conscience and freedom of religion, freedom of speech and freedom of opinion without being intervened by any one; the right to be equally treated of minority community before the law and so on.

(ii) Social, economic and cultural rights. Along with the system of human rights, social, economic and cultural rights were officially codified aftermath of the Second World War, with the adoption of the Universal Declaration of Human Rights by the United Nations in1948, and particularly the International Covenant on Economic, Social and Cultural Rights in 1966. A set of rights includes rights of every individual to equal and favourable working conditions and rights of freedom to set up or join trade unions (Articles 6, 7, and 8); the right to social security, including social insurance (Article 9); the right to get married, including right of mothers to convalescence before and after giving birth, and have mechanisms for protecting children (Article 10); the right to enjoy suitable living standards, including the aspects of food, clothing, accommodation and improving living standards" (Article 11); the right to education etc. Such rights are all aimed at developing comprehensively personality and sense of human ethics; establishing conditions and fair and equal treatment towards every citizen in society in the economic, cultural and social spheres.

(iii) Personality rights are rights closely associated with each individual and are non-transferable unless as prescribed by law or there is any change. There are many ways to classify personality rights. For example rights, or by generation, can be classified into non-asset-related group and asset-related group; by right-holder, can be classified into two groups: the group of personality rights of individuals and the group of personality rights of other subjects (rather than individuals)... In addition, there are other ways to classify, such as by object of right; by period of protection; by characteristics of the act of violation and so on.

* The promotion and protection human rights in the domain of Civil Law

In every country, human rights are assured and protected by the entire legal system, from public law to private law; from constitutional law, administrative law, criminal law and others to civil law, labour law, law on marriage and family. Each legal sphere assures and protects human rights and citizens' rights by their own specific ways and methods.

Assuring human rights in the domain of Civil Law is to create premises, and political, economic, social, legal and organizational conditions for individuals, citizens' organizations to exercise their legitimate rights, freedom, and benefits that have been acknowledged by civil law (Mike, 2016). The promotion and protection human rights determine legal measures, organizational measures, and mechanisms for protecting human rights and citizens' rights upon violation by public bodies or by other subjects in order to restore the violated civil rights. Assuring human rights in the domain of Civil Law is of critical significance in improving the legal norms in the domain of Civil Law and contributes to improving the feasibility of civil codes in reality (Ngoc Anh, 2015).

Firstly, the Civil Code plays an especially important role in social management. It is not only a firm politico-legal confirmation but also helps enforce laws on human rights and citizens' rights. All individuals have the legal capacity are equal.

Secondly, in the development process of each country, besides the advantages achieved, there are also many emerging challenges (such as property relation, racial discrimination, legal persons or increase in cases of violating human rights etc.). In order to maintain social order and rules, assuring human rights in the domain of Civil Law is of great significance in providing the people and the State management bodies with a solid legal corridor in order to better protect human rights, citizens' rights in the domain of Civil Law.

Thirdly, assuring human rights in Civil Law assists countries, especially developing countries, in keeping up 
with the general development of the world. That countries The acknowledge, respect and commitment of countries to assure and protect human rights based on international treaties will create a uniform social environment standardizing regulations, and making it possible for socio-economic development.

Fourthly, in recently, violations of human rights in the domain of Civil Law have been increasing both in terms of number and degree, particularly in developing countries like Vietnam. This requires that countries should lay down more regulations in order to improve human rights, and help the people and State bodies in carrying out activities of protecting and managing human rights.

\section{Human Rights and the Promotion and Protection Human Rights under the Civil Code of Vietnam}

\subsection{Human Rights in Vietnam's Civil Law}

The Civil Code plays an extremely important role in establishing and assuring rules and order of each country, with the effect of regulating basic relations of society, of each citizen, family, agency, and organization. The Civil Codes of Vietnam through the years have been supplemented and improved towards enhancing human rights on the basis of "strengthening the legal grounds with respect to the responsibilities of State bodies in making, promulgating in a timely and synchronous manner and arranging to put into execution of the law and international treaties in which Vietnam is a member with respect to human rights and citizens' rights in the civil, political, economic, socio-cultural spheres" (according to the Resolution on Strategy for Building and Improving Vietnam's Legal System).

Since the first Civil Code as adopted by the National Assembly of Vietnam in 1995, till 2005, when the Civil Code 2005 was adopted and most recently, at the 10th Plenum of the 3rd National Assembly (November 24), the Civil Code 2015 (Law No. 91/2015/QH13) was officially promulgated, most expressly displayed the rule of respecting the self-agreement and equality among subjects in civil relations and reduced the State's administrative intervention in civil relations. This helps assure and enhance human rights in the legal system in general and the Civil Code in particular. The 2015 Civil Code consisting of 689 Articles, divided into 6 parts and 27 chapters, is the basic law of the legal system that regulates the civil relations formed on the basis of equality, freedom of will, independence of property and self-responsibility of the parties involved. The 2015 Civil Code was written on the basis of complying with international treaties on the protection of human rights in the domain of Civil Law in which Vietnam is a member. Specifically, all people, irrespective of races, colour, national origin or ethnic group, are assured the right to equality before the law, particularly in enjoying such civil rights as:

(i) Civil and political rights

Civil and political rights under the 2015 Civil Code 2015 are the rights to be assured by the State that any person whose personality, economic, cultural, social rights are violated will all receive effective consequence remedies. At the same time, their request for remedies will be assured to be enforced by competent bodies. Civil and political rights are one of the important means to help the people protect their own legal rights and benefits. In order to assure civil and political rights in the domain of Civil Law, the Civil Code of 2015 was written, with specific and clear provisions related to the damage liability coverage, mainly concentrated from Article 579 to Article 608 in Chapter XIX and Chapter XXX of the 2015 Civil Code.

(ii) Social, economic and cultural rights

Throughout the 27 chapters of the 2015 Civil Code , with the focus on Chapter IV "Legal Persons", all the provisions are to create maximal conditions for the people to have their human rights assured in their socio-economic activities, namely: the right to work, the right to freedom of selecting jobs and having equal and favourable working conditions, to be protected against unemployment, to be equally paid for equal work, to be equally and satisfactorily paid; the right to set up and join trade unions; the right to housing; the right to have access to public health, healthcare, social security and services; the right to education and training; the right to religion, etc.

(iii) Personality rights

The 2015 Civil Code lists a wide range of personality rights (from Article 25 to Article 39), including: the right to have full name; the right to change full name; the right to determine ethnic group; the right to declare birth, to declare death; image rights; the right to life, protection of the safety of life and physical health; the right to protection of honour, dignity, reputation; the right to privacy; the right to marriage, equal rights to both spouses; right of donating body's parts; the right of receiving body's parts; the right of redefining gender; the right to enjoy mutual care among family members; the right to divorce and so on. In addition, from Article 677 to Article 687 in Chapter XXVII of the Civil Code 2015, there are some more statutory regulations applicable to property relations, personal relationships. 
Personality rights of individual are fully concretized under the 2015 Civil Code in order to define the subject status of the individual in civil relations that are specified in the Constitution and the international treaties in which Vietnam is a member. Especially, for the first time in the legislation history, the issue of redefining gender is provided for under the Article 37 of the 2015 Civil Code as follows: "The sex reassignment shall comply with regulations of law. Each surged transgender has the right and obligation to apply for change of civil status affairs as prescribed in law on civil status affairs and has the personal rights in conformity with the transformed gender as prescribed in this Code and relevant laws".

In recent years, the Civil Code of Vietnam has made remarkable successes in the promotion and protection human rights, particularly not only for Vietnamese but also for foreign citizens in Vietnam. In the most general manner, the Code conforms to international conventions, law and practices; however, when putting into practice, it still appears to have certain limitations as follows:

\section{* Successes}

Firstly, the Civil Code has basically institutionalized in a fairly full and specific way the measures to acknowledge, respect, protect and assure human rights, citizens' rights in every area of the civil life. At the same time, it has also created an effective legal mechanism for acknowledging, respecting, protecting and assuring citizens' rights of the subjects, particularly protecting the rights and benefits of the disadvantaged parties. The Civil Codes regulates civil relations on the basis of democracy, principle of equality, mutual agreement and responsibility among the subjects, maximum reduction in administrative affairs of State management bodies in civil transactions.

Secondly, in the latest Civil Code, personality rights of individual have been fully concretized in order to define the subject status of the individual in the civil relations that are specified in the Constitution and the international treaties in which Vietnam is a member. Especially, as mentioned above, for the first time in the history of constitutionalism, the issue of redefining gender is acknowledged. This stipulation establishes a legal mechanism for fighting against discriminatory treatment towards people having sex changes, and assures that they have their legal status equal to that of other individuals, as well as the transparency in exercising their personality rights and assets in civil relations. This can meet the needs of a proportion of citizens in society, in conformity with the general international practices.

Thirdly, the Civil Code has become the code with the position and the role of the general law of the legal system to protect human rights formed on the basis of equality, freedom of will, independence of assets, and self-responsibility. The Civil Code guarantees generality, predictability, and feasibility, on the other, timely meets the requirements of the regular and continuous development of the social relations that fall within the governing scope of civil law. The Civil Code helps overcome the contradictions, overlapping of the legal system with respect to ownership, obligations, and contracts, thus making contribution towards guaranteeing the utility and comprehensiveness of the legal system in general and the law on human rights in particular. For example, in Article 385 of the 2015 Civil Code, the word "civil" next to the word "contract" is rejected; whereas the Article 385 of the 2005 Civil Code stipulates that: "contract means an agreement between parties in relation to the establishment, modification or termination of civil rights and obligations". This amendment is of great significance which highlights the transparency in activities of applying and putting law into practice. The rejection of word "civil" in the definition of contract in the 2015 Civil Code has widened the governing scope of the Civil Code to all kinds of contracts, including civil contracts, labour contracts, business or sales contracts, in conformity with the practical application of law.

Fourthly, the provisions on the protection of human rights in the Civil Code has been developed and the development of the provisions that are conformable with the practice of the civil law, as well as the cultural values, good customs, traditions and ethics of Vietnam, in combination with learning from the success experiences in establishing civil codes of some countries, particularly those with the legal traditions similar to that of Vietnam. For instance, the Article 645 "Heritage used to worship" stipulates specifically and expressly that the use of heritage for the purpose of upholding the custom of ancestor worship has been in existence for thousands of years; particularly, "Where a testator designates part of his or her estate for worship purposes, such part of the estate shall not be distributed among the heirs and shall be delivered to the person appointed in the will to manage for worship purposes. If such appointee fails to implement strictly the will or the agreement of the heirs, the heirs have the right to appoint another person to manage for worship purposes."

Fifthly, the Civil Codes, over the years, has gradually assured that they are more and more in conformity with international conventions and practices concerning the protection of human rights, such as the Convention on Civil and Political Rights (1982); Convention on Economic, Social and Cultural Rights (1982); Convention on 
Removal of All Forms of Discriminatory Treatment towards Women (1982); Convention on Children's Rights, (1990)...which facilitates Vietnam's comprehensive integration process into the general playground of the world; making a contribution towards building the process of social, economic and cultural development of the country, and bringing Vietnam into the group of countries with specific statutory regulations on the protection of human rights over the world.

\section{* Limitations}

Nevertheless, in the implementation process, in the face of the requirements for acknowledging, respecting, protecting, assuring human rights and citizen rights, and improving the socialist-oriented market economic institution, the Civil Code still shows some following limitations and problems as follows:

Firstly, the previous Civil Codes failed to ensure the principle that civil rights could only be restricted by law in special cases; failed to establish an effective legal mechanism for protecting bona fide third parties, goodwill parties, and disadvantaged parties in civil relations etc. Many of the provisions on subjects, transactions, representation, obligations, contracts, and inheritance remain unreasonable, infeasible. For example, the Article 130 of the 2005 Civil Code states that: "When a civil transaction is established or performed by a minor or by a person who has lost his/her civil act capacity or whose civil act capacity is restricted, the Court shall, at the request of the representative of that person, declare such transaction invalid, if it is provided for by law that such transaction must be established and performed by the representative of that person". This stipulation is aimed at protecting the rights and benefits of the juvenile, and person without or with limited civil behaviour capacity, but failing to guarantee fully the will to volunteer to enter into an agreement of such subjects.

Secondly, a number of provisions of the previous Civil Codes did not really create favourable conditions for the promotion and protection human rights in the socio-economic terms such as: (1) the Civil Codes before the 2015 Civil Code contained many provisions on ownership while had very few provisions on other kinds of rights to assets (rights of the people who are not asset owners. (2) Regarding the issue of protecting individual ownership, legal mechanisms for carrying out this task were not always acknowledged, for instance, no acknowledgment of the principle of rights of all owners, no differentiation of the form of ownership, and economic sectors that were equally recognized and protected by the law. These shortcomings made it difficult for the application, management of the law in the promotion and protection human rights of individuals and State bodies.

Thirdly, despite its many new points and remedies to shortcomings of the previous codes, the 2015 Civil Code only stipulates that the subjects of civil relations are individuals and legal persons in Chapter IV: "General regulations on legal persons", together with some separate regulations on the joining civil law of family household members (the 2015 Civil Code), cooperative groups, and other organizations without the legal person status. Some legal experts assume that since there are a lot of differences between families and cooperative groups, it is impossible to include both subjects in the same article and thus this provision still fails to ensure the thoroughness and unity with respect to the content. It is this that has reduced a basic part of activities of assuring the legitimate rights and benefits of each object group. For instance, when involving in civil transactions, family households, if wishing to exercise the right to establish and carry out civil transactions, have to do that through their representatives, thus increasing the complexity in defining individual property rights.

Fourthly, the 2015 Civil Code does not stipulate the case of permitting compulsory purchase, requisition in the "state of emergency, prevention of natural disasters" and indemnity under the latest constitution - the Constitution of 2013. Therefore, once emergency cases occur, management agencies have insufficient legal grounds for persuading the people to give their consent; at the same time, the people do not have grounds for protecting their rights and benefits in the case of compulsory purchase, requisition of assets which evildoers take advantage to seek their own profit or group profit.

Fifthly, as the awareness of human rights by some local authorities, particularly in remote, innermost, outermost, border, island regions still fails to catch up with the progress of human rights, the level of improvement of the legal constitution according to the specific local conditions remains limited.

\subsection{The Promotion and Protection Human Rights in Vietnam's Civil Law}

Regarding legal grounds, human rights protection activities in the domain of civil law of Vietnam are specified in Chapter II "Establishing, implementing and protecting civil rights" of the 2015 Civil Code. Accordingly, If a person has his/her civil rights violated, he/she may protect them himself/herself as prescribed in this Code, other relevant laws or request competent authorities to: recognize, respect, protect and guarantee of his/her civil rights; order the termination of the act of violation; order a public apology and/or rectification; order the performance of civil obligations; order compensation for damage; cancellation of isolated unlawful decision of competent 
agencies, organizations or persons and other requirements specified by law (Article 11 of the Civil Code 2015). The self-protection of human rights shall conform to the characteristics and the level of violation of such civil rights and shall not be contrary to the basic principles of the civil law. In case the civil rights are violated or in dispute, the protection will comply with the code of civil procedure before courts or arbitration.

To avoid the case in which human rights are taken advantage, resulting in the violation of another subject's human rights contrariwise, the Civil Code of 2015 also stipulates a limit to the exercise of the civil rights. Specifically, individuals and legal people shall not abuse their civil rights to cause damage to others, or to violate their obligations or to achieve other purposes against the law.

For the time being, human rights protection activities in Vietnam are under the great impact of the socialist-oriented market economy and international integration. This process will help Vietnam improve its socio-economic conditions, facilitate activities of assuring and solving human rights issues towards diversifying the needs and improving the resources, and create favourable opportunities for the rapid and sustainable economic development process - the necessary condition for the promotion and protection human rights in Vietnam. At the same time, this will make it possible for a change in the thinking of human rights; push forward and reach an asymptote in human rights protection activities in an ever comprehensive and profound manner, through which, human rights will be assured at both national and international levels.

Under such conditions, human rights protection activities in the domain of civil law of Vietnam have made numerous significant achievements. The State and socio-political organizations were positive and proactive in fulfilling their obligation of human rights protection; the constitutional system for the promotion and protection human rights has gradually been established towards perfection; along with that is the active participation of the people and social organizations in human rights protection activities. The efforts to express opinions about the promotion and protection human rights of Vietnam have been greatly recognized and appreciated by the international community with the fact that Vietnam was elected as Member of Human Rights Committee of the United Nations (t2001 - 2003), Non-permanent Member of the United Nations Security Council ( 2008 - 2009).

However, besides the successes made, human rights protection activities in the domain of Civil Law still show their limitations in the way of organizing and operating of some institutions related to the promotion and protection human rights and in the practice of human rights protection for the people. Furthermore, the mechanism for promotion and protection human rights at present is ineffective, since there is no agency responsible for promotion and protection human rights, and no strict regulations on handling denouncements and violations of human rights in the domain of Civil Law, thereby leading to the failure to control and handle thoroughly cases of human rights violations in the domain of Civil Law, and creating gaps for some people to carry out their acts of violating the law.

A serious problem concerning human rights violations in 2014 was the case of the Hanoi-based Viet Hong Company when they supplied phone bugging software to thousands of customers, with 14,140 phone devices installed with tracking software. Upon customer request, Viet Hong would install the software for trial use within 24 hours. In this way, all data such as phone directory, messages, outgoing and incoming calls, surround sound recordings, images, videos, travel routes, and current locations of the devices under surveillance should be recorded and sent to a server by the software in around 5-10 minutes. Only by logging in Viet Hong's website users could review all the information of the phone devices under surveillance. By this way, thousands of users of this firm's software seriously violated the right to privacy of personal information, and to assure safety of personal privacy, mail, phone privacy of others as specified in Article 38 of the 2015 Civil Code. Although the violation was in the domain of Civil Law, the case was taken into consideration and brought under criminal prosecution due to its level of severity; if not seriously handled, it would create a bad premise, in disagreement with the requirement for hi-tech crimes combating and prevention at present. The case has shown that there are still many limitations in assuring and protecting the safety of information in Vietnam, thus affecting the quality of human rights protection activities in the domain of Civil Law.

Also, human rights protection activities in the domain of Civil Law of Vietnam also reveal some limitations in the allocation of material resources. Material conditions are the necessary factor for the promotion and protection human rights, however, due to economic difficulties; the country lacks conditions for serving activities of researching, dealing with and overcoming the damages caused by acts of human rights violation. Especially, for the time being, while science and technology are ever more rapidly developing, acts of dispersing and publicizing personal images and information on the Internet are spreading with higher frequency and at higher severity level. That the competent bodies with authority to deal with this are not fully equipped with the science and technology means necessary for the implementation will be a big obstruction to legitimate human rights 
protection activities.

The cause of the above limitations is that the regulations on the promotion and protection human rights in the domain of Civil Law lack comprehensiveness, and cannot cover all possible happenings, thereby leading to the fact that governing law is enacted after the occurrence of the act of violation. In addition, the limited awareness of human rights in the law of a number of leaders, managers and people in most remote, innermost areas under insufficient conditions (such as unfavourable natural-geographical conditions, shortage of resources, penetration of international vices, etc.) is also one of the causes of the limitations in human rights protection activities in the civil law domain of Vietnam.

\section{Recommendations and Solutions}

From the success and limitations of the regulations on human rights and human rights protection activities in the civil law domain of Vietnam, the author would like to propose the following suggestions and solutions for dealing with the issue of human rights in the domain of Civil Law, particularly under the conditions of deep and extensive international integration like today:

+ Regarding the activity of promulgating legal documents:

Firstly, the State should review the system of legal normative documents in order to repeal the legal documents which are contradictory, overlapping or unconformable to the development practice; and to ensure the constitutionality, utility, feasibility, publicity, transparency, accessibility, and ease of the implementation of legal normative documents on human rights to meet the practical needs of the society.

Secondly, Vietnam should positively and proactively participate in international conventions and forums on human rights at the global or regional scale. Proactively entering into international conventions on human rights will enable Vietnamese lawmakers to have more grounds and corridors for improving the entire legal system in general and Civil Law in particular; and to ensure that legal regulations will be made on the basis of the respect for human rights, and regarding human rights as the core in law-making process.

Thirdly, the State should continue improving the legal institution towards the optimal protection of rights, benefits and means to guarantee rights and benefits of individuals. In the current social development process, there still remain some limitations in giving priority to collectives of individual rights (e.g. taking advantage of the use of social networks to vilify, or smear the honour and human dignity of others, or to sell products online). Hence, in law-making activities, lawmakers should study thoroughly measures to assure fair regulations for all people.

Fourthly, as for civil-political rights, in law-making activities, lawmakers should attach special importance to improving the democratic, open, and transparent institution so as to assure the rights of the people directly or indirectly involved in building and controlling the State, and the rights to express their opinions. These are extremely important means not only for helping individuals protect their legitimate rights and benefits but also serve as effective grounds for State bodies to better manage human rights protection activities. In addition, regulations on socio-cultural rights should be ensured to be established towards compensating for the disadvantaged parties, such as improving social security policy (particularly social insurance, relief, and care for the beneficiaries of policies and people in difficulties or at a disadvantage) and so on.

+ Regarding the activity of ensuring the implementation of regulations on human rights:

Besides attaching special importance to law-making activities, in order to ensure human rights through Civil Law enforcement, the competent State bodies should strengthen legislation in protecting human rights. As a matter of fact, cultural recession and human rights violations today tend to increase in terms of quantity and level of severity. The typical of this are the big problems recently such as the emission and discharge of toxic into the environment from the works of Formosa and Vedan; or the production of unhygienic and unsafe goods; bureaucratic and irresponsible habits in supplying public services, etc. This demands the State to take more measures to handle these violations seriously. Some drastic measures may include forfeiting business licenses, considering criminal prosecution, increasing administrative penalties and so on in order to enhance the deterrent effects on acts of violating human rights. This will be the very manifestation of the State's respect for and protection of human rights as well as the guarantee of the sustainable development of the country.

An independent agency responsible for human rights protection should also be conceived and established, along with a strict regulation on dealing with denouncements and violations of human rights in the domain of Civil Law. To carry out this mission, the competent State bodies should set up a specific and detailed plan, and refer to the successful experiences of other countries in human rights protection activities in the domain of Civil Law. 
On the other hand, the State should also intensify investment in human rights protection activities in the terms of manpower, material resources, and financial resources; ensure to create necessary conditions for the staff to carry out human rights protection activities, as well as select, train and build the workforce with knowledge, skills and competence for management. This will be of special importance since in the face of increasing degree and more complicated nature of human rights violations, a good and capable workforce will be a prerequisite for the protection of the people's legitimate rights and benefits.

\section{Conclusion}

The article has analyzed and assessed the successes and limitations in the practice of human right protection activities under Vietnam's civil law in recent times, It has proposed suggestions and solutions. The research findings show that the Civil Code through the years has made remarkable successes in the promotion and protection human rights, especially, not only for the Vietnamese but also for foreigners living and working in Vietnam. The legal regulations in the domain of Civil Law conform to international conventions, laws, and practices. Nevertheless, when putting into practice, there remain certain limitations. For example, a number of provisions of the current Civil Code fail to meet the human rights legislations or do not really create favourable conditions for the promotion and protection human rights in the economic and social aspects. These limitations originate from the fact that the regulations on the promotion and protection human rights in the domain of Civil Law lack comprehensiveness, and cannot cover all possible happenings, thereby leading to the fact that governing laws are often adopted after the actual occurrence of violations.

To overcome the limitations of human rights protection activities in the civil law domain of Vietnam, the article offers some suggestions to improve human rights in the domain of Civil Law, including suggestions for activities of promulgating legal documents, for competent State bodies, and for activities of ensuring the implementation of regulation on the promotion and protection human rights. The State therefore should be proactive in taking comprehensive measures in order to create solid a legal corridor for the management activity of the State bodies in the domain of Civil Law and activity of protecting the people's legitimate rights and benefits, making a contribution towards successfully building a socialist regime - a regime for the people in Vietnam.

\section{References}

Anh, N. (2015). Sửa đổi Bộ luật Dân sự để bảo vệ tốt hơn quyền và lợi ích hợp pháp của người dân. trang thông tin điện tử Hệ Phát thanh Đối ngoại Quốc gia, Đài Tiếng nói Việt Nam.

Donnelly, J. (2007). The Relative Universality of Human Rights. Graduate School of International Studies University of Denver. http://dx.doi.org/10.1353/hrq.2007.0016.

Frick, M. (2016). Funding for tuberculosis research - an urgent crisis of political will, human rights, and global solidarity. International Journal of Infectious Diseases, In Press, Corrected Proof.

Gruodyte, E., \& Kirchner, S. (2016). Legal aid for intervenors in proceedings before the European Court of Human Rights. International Comparative Jurisprudence, 2(1).

Mourgon, J. (1995). Human rights. French University Publishing.

Seymour, D., \& Pincus, J. (2008). Human Rights and Economics: The Conceptual Basis for their $\begin{array}{lllll}\text { Complementarity. Development } & \text { Rolicy }\end{array}$ http://dx.doi.org/10.1111/j.1467-7679.2008.00415.x

Shor, E., Filkobski, I., Bloom, P. B.-N., Alkilabi, H., \& Su, W. (2016). Does counterterrorist legislation hurt human rights practices? A longitudinal cross-national analysis. Social Science Research, 58.

United Nations. (2006). Human Rights: Questions and Answers. United Nations.

\section{Copyrights}

Copyright for this article is retained by the author(s), with first publication rights granted to the journal.

This is an open-access article distributed under the terms and conditions of the Creative Commons Attribution license (http://creativecommons.org/licenses/by/4.0/). 